\title{
PENGARUH STRATEGI PEMBELAJARAN, GAYA BELAJAR, SARANA PRAKTIK, DAN MEDIA TERHADAP HASIL BELAJAR PATISERI SMK SE-GERBANGKERTASUSILA
}

\author{
Siti Nurul Aini \\ SMKN 1 Dlanggu \\ nqsiti@yahoo.com \\ Putu Sudira \\ Universitas Negeri Yogyakarta \\ putupanji@uny.ac.id
}

\begin{abstract}
Abstrak
Penelitian ini bertujuan untuk mendeskripsikan pengaruh strategi pembelajaran, gaya belajar peserta didik, sarana praktik, dan media pembelajaran terhadap hasil belajar Patiseri di SMK SeGerbangkertasusila.Penelitian ini adalah penelitian expostfacto yang bertujuan untuk menjelaskan pengaruh strategi pembelajaran, gaya belajar peserta didik, sarana praktik, dan media pembelajaran terhadap hasil belajar Patiseri di SMK Se-Gerbangkertasusila.. Penelitian ini dilaksanakan di SMK Se-Gerbangkertasusila yang mempunyai program studi patiseri. Sampel penelitian ini sebanyak 337 siswa. Pengumpulan data melalui angket. Analisa data yang digunakan adalah analisi regresi dan korelasi dengan tarafkesalahan 0,05. Hasil penelitian ini adalah sebagai berikut. 1) Sebanyak 51,04\% siswa berpendapat bahwa strategi pembelajaran di SMK Se-Gerbangkertasusila berkategori sedang; 65,58\% siswa memiliki gaya belajar berkategori sedang; 53,71\% siswa berpendapat bahwa sarana praktik berkategori sedang, 47,18\% siswa berpendapat bahwa media pembelajaran berkategori sedang; dan 62,31\% siswa memiliki nilai di rapor berkategori sangat tinggi. 2)Ada pengaruh positif dan signifikan antara strategi pembelajaran terhadap hasil belajar mereka $\left(r_{x I v}=0,735 ; p<0,005\right)$; ada pengaruh positif dan signifikan antara gaya belajar siswa terhadap hasil belajar $\left(r_{x 2 y}=0,567\right.$; $p<0,005)$; terdapat pengaruh positif dan signifikan antara sarana praktik terhadap hasil belajar $r_{x 3 y}$ $=0,222 ; p<0,005)$; terdapat pengaruh positif dan signifikan antara media pembelajaran terhadap hasil belajar $\left(r_{x 4 y}=0,735 ; p<0,005\right)$; terdapat pengaruh positif dan signifikan secara bersama-sama antara strategi pembelajaran, gaya belajar, sarana praktik, dan media pembelajaran terhadap hasil belajar $\left(r_{x I, x 2, x 3, x 4, y}=0,749 ; p<0,005\right)$.
\end{abstract}

Kata Kunci: strategi pembelajaran, gaya belajar, sarana praktik, media pembelajaran, patiseri

\section{THE EFFECT OF STUDENT'S LEARNING STRATEGIES, LEARNING STYLES, PRACTICE FACILITIES, AND MEDIA ON LEARNING OUTCOMES OF VOCATIONAL PASTRY AND BAKERY IN GERBANGKERTASUSILA}

\begin{abstract}
This study aimed to describe the effect of student's learning strategies, learning styles, practice facilities, and instructional media on learning outcomes in vocational pastry and bakery in Gerbangkertasusila.This research is expostfacto research to describe effect of student's learning strategies, learning styles, practice facilities, and instructional media on learning outcomes in vocational pastry and bakery in Gerbangkertasusila.. This research was conducted at SMK Gerbangkertasusila having patiseridepartment. The sample was 337 students establised using a questionnairetechnique. The data were collected through questionnaires. Data analyze using correlation and regretation with correction 0,05. The results of the study are as follows :1) As many as $51.04 \%$ of students found learning strategies in SMK Gerbangkertasusila being in a fair category; $65.58 \%$ students have a moderate learning style category, $53.71 \%$ of students found the
\end{abstract}


practicum facilitiesbeing in afaircategory; $47.18 \%$ of students found the instructional media being in afaircategory and $62.31 \%$ of students have veryhigh grades in their report books.2) There is a positive and significant correlation between the learning strategies on student learning outcomes in patiseriCatering Skills Program SMK Gerbangkertasusila $\left(r_{x I y}=0.735, p<0.005\right)$; there a positive and significant correlation between students'learning styles on learning their outcomes $\left(r_{x 2 y}=0.567\right.$, $p<0.005)$, there is a positive and significant correlation between the practicum facilities on students learning outcomes $\left(r_{x 3 y}=0.222, p<0.005\right)$, there is a positive and significant correlation between instructional media on the students' learning outcomes $\left(r_{x 4 y}=0.735, p<0.005\right)$, there is a positive and significant effect oflearning strategies, learning styles, practicum facilities, and instructional media in aggregate on the students' learning outcomes $\left(r_{x l, x, x, x, x 4, y}=0.749, p<0.005\right)$.

Keywords: learning strategies, learning styles, practice facilities, and instructionalmedia, pastry and bakery

\section{PENDAHULUAN}

Salah satu keberhasilan peserta didik dalam pendidikan ditunjukkan dengan hasil belajar. Pada kenyataannya ditemukan tuntutan hasil belajar pada peserta didik semakin tinggi sementara strategi pembelajarannya biasa-biasa saja. Hal inilahyang menyebabkan hasil belajar peserta didik kurang memuaskan sebagaimana diharapkan oleh sekolah, orangtua,dan peserta didik itu sendiri.

Peningkatan hasil belajar peserta didik dalam pembelajaran dipengaruhi oleh berbagai faktor yang ada pada diri peserta didik maupun lingkungan sekitar peserta didik. Empat faktor yang diduga turut mempengaruhi hasil belajar peserta didik adalah strategi pembelajaran, gaya belajar peserta didik, sarana praktik, dan media pembelajaran untuk memperoleh hasil belajar yang optimal. Fungsi pendidikan salah satunya adalahmembentuk sikapdanorientasi peserta didikterhadap belajar, menggunakan strategi pembelajaran yang tepat untuk menanamkan pengetahuan serta untuk mengembang-kan keterampilan belajar secara efektif. Pengalaman guru dalam proses pembelajaran mempengaruhi strategi pembelajaran yang dipakai. Sedangkan pengalaman peserta didik akan membentuk gaya belajarindividual,sepertiyangdiajarkanba gaimanabelajar.

Patiseri merupakan salah satu pengetahuan dalam pengolahan dan penyajian makanan, khususnya mengolah dan menyajikan berbagai jenis kue. Patiseri berasal dari Bahasa Perancis yaitu Pạtisserie yang artinya kue-kue. Dengan demikian patiseri dapat diartikan sebagai ilmu pengetahuan yang mempelajari tentang seluk beluk kue baik kue kontinental, oriental maupun kue Indonesia mulai dari persiapan, pengolahan sampai pada penyajiannya. Saat ini patiseri dipelajari sebagai suatu ilmu dan seni dalam mengolah dan menyajikan berbagai macam kue, baik kue-kue tradisional maupun modern. Kue dapat disajikan dalam berbagai kesempatan, selain memberikan rasa kenyang, juga kue berfungsi sebagai dekorasi ataupun hiasan. Sekarang ini mutu dan rasa kue telah jauh berbeda (Farida, 2008 p, 2).

Di Sekolah Menengah Kejuruan, Patiseri adalah salah satu program keahlian yang masuk dalam bidang keahlian Tata Boga. Program keahlian Patiserti difokuskan untuk bagaimana membuat kue/roti, baik tradisional maupun yang sudah modern. Secara khusus tujuan program keahlian Patiseri adalah membekali peserta didik dengan keterampilan, pengetahuan, dan sikap agar berkompeten mengolah dan menyajikan produk Patiseri, kue dari adonan cake dan rich cake, serta kue dari adonan menggunakan bahan pengembang (http://smkn6sby.sch.id/patiseri.php).

Di Sekolah Menegah Kejuruan (SMK), Patiseri adalah salah satu kompetensi keahlian yang masuk dalam program studi keahlian Tata Boga yang masuk dalam rumpun bidang studi keahlian Seni, Kerajinan dan Pariwisata. Kompetensi keahlian Patiseri difokuskan untuk bagaimana membuat kue/roti, baik tradisional maupun yang sudah modern. Secara khusus tujuan kompetensi Patiseri adalah membekali peserta didik dengan keterampilan, pengetahuan, dan sikap agar berkompeten mengolah dan menyajikan produk patiseri, kue dari adonan cake dan rich cake serta kue- 
kue dari adonan yang menggunakan bahan pengembang (Farida, 2008 p,3).

Dari prasurvei yang telah dilakukan, ternyata hanya SMK Negeri 6 dan SMK Negeri 8 Surabaya saja yang mempunyai kompetensi keahlian Patiseri. SMK Negeri 1 Cerme Gersik, SMK Negeri 1 Buduran Sidoarjo, SMK YPM Sepanjang Kabupaten Sidoarjo, SMK Negeri 2 Jombang, SMK Negeri 1 Kertosono, SMK Negeri 1 Dlanggu Mojokerto dan SMK PGRI Sooko Mojokerto, Patiseri dijadikan sebagai muatan lokal bagi SMK yang mempunyai kompetensi keahlian Tata Boga.

Dari segi fasilitas untuk menunjang pembelajaran Patiseri, SMK Negeri 6 Surabaya, SMK Negeri 8 Surabaya, SMK Negeri 1 Buduran Sidoarjo dan SMK Negeri 1 Cerme Gersik mempunyai peralatan Patiseri yang sangat lengkap, tetapi di SMK Negeri 1 Cerme Gersik kelengkapan fasilitas tidak diikuti tidak diikuti oleh pemasaran hasil/produk Patiseri karena letaknya di pedesaan dan kurangnya ketertarikan penduduk sekitar terhadap produk patiseri yang di nilai terlalu mahal. Sedangkan SMK YPM Sepanjang Kabupaten Sidoarjo, SMK Negeri 2 Jombang, SMK Negeri 1 Kertosono, SMK Negeri 1 Dlanggu Mojokerto dan SMK PGRI Sooko Mojokerto memiliki fasilitas cukup lengkap untuk menunjang pembelajaran Patiseri. Walaupun hanya sebagai program kecakapan hidup bagi peserta didik, Patiseri di SMK negeri 1 Lamongan dapat di katakan sukses karena dapat membangun jiwa kewirausahaan peserta didik karena mereka dapat memasarkan produk Patiseri di kantin sekolah. SMK Negeri 1 Buduran Sidoarjo juga dikategorikan sukses meskipun Patiseri hanya sebagai Muatan lokal karena SMK Negeri 1 Sidoarjo mempunyai kelas khusus yaitu kelas Wirausaha, hasil produk patiseri di pasarkan di lingkungan sekolah atau di luar sekolah, khususnya untuk kelas XI harus memasarkan produk di luar sekolah yang tujuannya untuk berani unjuk hasil produk di luar sekolah. Dari segi strategi pembelajaran, semua sekolah yang di kunjungi untuk keperluan survei memiliki banyak kesamaan antara lain: pembelajaran teori 20\% untuk mengenal lingkup Patiseri, $70 \%$ pembelajaran berupa praktik dalam membuat produk Patiseri, sedangkan 10\% adalah pemasaran secara langsung produk Patiseri.

Keberhasilan pembelajaran Patiseri tidak hanya dilihat dari pengetahuan peserta didik tentang Patiseri dan produk yang dihasilkan, tetapi yang lebih penting adalah memasarkan produk Patiseri yang telah dibuat oleh peserta didik kepada lingkungan sekitar, baik di lingkungan sekolah seperti kantin, maupun di lingkungan luar sekolah, seperti pesanan dari masyarakat sekitar. SMK Negeri 6 Surabaya, SMK Negeri 8 Surabaya, SMK Negeri 1 Buduran Sidoarjo, dan SMK Negeri 1 Lamongan dinilai sudah berhasil dalam pembelajaran Patiseri karena memenuhi tiga hal diatas yaitu pengetahuan, produk, dan pemasaran hasil produk Patiseri. SMK YPM Sepanjang Kabupaten Sidoarjo, SMK Negeri 2 Jombang, SMK Negeri 1 Kertosono, SMK Negeri 1 Dlanggu Mojokerto dan SMK PGRI Sooko Mojokerto dinilai kurang berhasil dalam pemasaran produk patiseri karena kurang minatnya warga sekolah terhadap produk Patiseri. Sedangkan SMK Negeri 1 Cerme Gersik walaupun memiliki peralatan Patiseri lengkap, tetapi belum dimanfaatkan secara maksimal untuk meningkatkan hasil belajar Patiseri karena peserta didik yang kurang tertarik terhadap muatan lokal Patiseri dan tidak adanya minat masyarakat sekitar terhadap produk Patiseri karena dinilai masih mahal.

Dari segi gaya belajar peserta didik, terdapat perbedaan antara peserta didik yang sekolah di perkotaan, pinggiran kota dan pedesaan. SMK yang berada di perkotaan, seperti SMK Negeri 6, SMK Negeri 8 Surabaya, SMK Negeri 1 Buduran Sidoarjo, SMK Negeri 1 Lamongan, SMK PGRI Sooko Mojokerto dan SMK Negeri 2 Jombang, gaya belajar peserta didik telah maju dengan memanfaatkan fasilitas yang ada di sekolah dan mencari ideide baru dalam bidang Patiseri. Bagi SMK yang berada di pinggiran kota, seperti SMK Negeri 1 Kertosono, SMK YPM Sepanjang Kabupaten Sidoarjo, gaya belajar peserta didik masih bergantung pada pengetahuan yang didapat dari guru, peserta didik enggan mencari literatur tentang Patiseri. Sedangkan bagi SMK yang berada di pedesaan, seperti 
SMK Negeri 1 Dlanggu Mojokerto, SMK Negeri 1 Cerme Gersik, walaupun fasilitas untuk belajar patiseri sangat lengkap, tetapi gaya belajar peserta didik kurang antusias dan tidak ada motivasi untuk mencari literatur yang mendukung pembelajaran Patiseri.

Hasil belajar Patiseri dilihat dari hasil nilai ujian semester rata-rata masih rendah. SMK Negeri 6, SMK Negeri 8 Surabaya, SMK Negeri 1 Buduran Sidoarjo, SMK Negeri 1 Lamongan, SMK PGRI Sooko Mojokerto dan SMK Negeri 2 Jombang masih ada kurang lebih 20-30 persen hasil belajar siswa yang masih di bawah KKM. Sedangkan untuk SMK Negeri 1 Kertosono, SMK YPM Sepanjang Kabupaten Sidoarjo yang mewakili SMK di pinggiran kota sekitar 25-40 persen hasil belajar siswa masih di bawah KKM. Terakhir, SMK Negeri 1 Dlanggu Mojokerto, SMK Negeri 1 Cerme Gersik sekirat 35-50 persen hasil belajar siswa masih di bawah KKM.

\section{METODE PENELITIAN}

Penelitian ini termasuk penelitian kuantitatif expostfacto yang digunakan untuk menguji hipotesis tetapi tidak memberikan perlakuan-perlakuan tertentu karena sesuatu sebab kurang etis untuk memberikan perlakuan atau memberikan manipulasi. Biasanya karena alasan etika manusiawi, atau gejala/peristiwa tersebut sudah terjadi dan ingin menelusuri faktor-faktor penyebabnya atau hal-hal yang mempengaruhinya (Sugiyono, 2012: 8).

\section{Tempat dan Waktu Penelitian}

Penelitian ini dilaksanakan di SMK Se-Gerbangkertasusila (Gresik, Jombang, Mojokerto, Surabaya, Sidoarjo, dan Lamongan) yang mempunyai Jurusan Patiseri, baik Patiseri sebagai program keahlian, muatan lokal (mulok), maupun program kecakapan hidup untuk peserta didik. Penelitian ini dilaksanakan selama 2 bulan, mulai bulan Oktober 2013 Nopember 2013.

\section{Populasi dan Sampel Penelitian}

Populasi dalam penelitian adalah semua peserta didik program keahlian Tata Boga SMK Se-Gerbangkertasusila yang berada di kelas XII dari SMKN Dlanggu Mojokerto,
SMKN 2 Jombang, SMKN 6 Surabaya, SMKN 8 Surabaya, SMKN 1 Cerme Gresik, SMKN 1 Buduran Sidoarjo, SMKN 1 Kertosono, dan SMKN 1 Lamongan yang berjumlah 599 siswa.

Pada penelitian ini, teknik sampling menggunakan sistem nonprobability samping. sampel hanya peserta didik kompetensi keahlian Tata Boga kelas XII SMK SeGerbangkertasusila karena peserta didik kelas XII telah mempelajari materi Patiseri di kelas XI sehingga mereka telah mengalami proses pembelajaran di kelas dengan strategi pembelajaran tertentu, gaya belajar tertentu, media pembelajaran tertentu, dan sarana praktik yang mendukung pembelajaran Pateriseri sebanyak 337 siswa.

\section{Variabel Penelitian}

Penelitian ini menggunakan paradigma ganda dengan dua variabel independen (bebas), yaitu Strategi pembelajaran, Gaya belajar peserta didik, Sarana praktik, Media pembelajaran, dan satu variabel dependen (terikat) yaitu Hasil belajar peserta didik

\section{Definisi Operasional}

Untuk menghindari kesalahan terhadap istilah-istilah operasional yang digunakan, maka perlu diberikan definisi operasional sebagai berikut.

Strategi pembelajaran adalah bagianbagian yang saling terkait antara satu dengan lain dengan komponen penting yang mendukung cara kerja pembelajaran serta cara mentransformasi pengalaman pembelajaran melalui teknologi pembelajaran. Strategi pembelajaran yang digunakan dalam pembelajaran Patiseri adalah demonstrasi dan praktik.

Gaya belajar adalah carabelajar yang lebih disukai pembelajar antara lain: gaya belajar visual, audio, dan kinestetik. Gaya belajar yang cocok dalam pembelajaran Patiseri adalah gaya belajar kinestetik.

Sarana praktik adalah segala sesuatu yang dapat dipakai sebagai alat dalam mencapai maksud atau tujuan pembelajaran (praktikum) dalam hal ini adalah tempat dilaksanakannya praktikum (workshop), peralatan dan bahan yang digunakan dalam melaksanakan praktikum yang ada di laboratorium Patiseri. 
Media pembelajaran adalah alat yangmempunyai fungsi menyampaikan pesan untuk mencapai tujuan pembelajaran. Media belajar yang digunakan dalam pembelajaran Patiseri berupa gambar visual.

Hasil belajar patiseri adalah kemampuankemampuan yang dimiliki peserta didik setelah iamenerima pengalaman belajarnya. Hasil belajar peserta didik dinilai pada perubahan tingkah laku, menyangkut aspek kognitif,afektif dan psikomotor yang diharapkan dapat dikuasai peserta didik setelah menerima atau menempuh pengalaman belajar. Dalam pembelajaran Patiseri, hasil belajar yang dinilai adalah penguasaan konsep, produk, dan kinerja (praktik).

\section{Teknik dan Instrumen Pengumpulan Data}

Teknik pengumpulan data yang digunakan adalah kuesioner (angket). Kuesioner merupakan teknik pengumpulan data yang dilakukan dengan cara memberikan seperangkat pertanyaan atau pernyataan tertulis kepada responden untuk dijawabnya.

Teknik pengumpulan data yang digunakan dalam penelitian ini adalah kuesioner (angket) dan dokumentasi. Jumlah instrumen yang akan digunakan dalam penelitian ini ada lima, yaitu: 1)Instrumen untuk mengukur strategi pembelajaran 2) Instrumen untuk mengukur gaya belajar peserta didik, 3) Instrumen untuk mengukur sarana praktik 4) Instrumen untuk mengukur media pembelajaran, 5) Instrumen untuk mengukur hasil belajar peserta didik.

Skala sikap yang akan digunakan dalam penelitian ini adalah Skala Likert. Skala Likert digunakan untuk mengukur sikap, pendapat dan pesepsi peserta didik tentang variabel yang ditanyakan dalam angket.

\section{Validitas dan Reliabilitas Instrumen}

Validasi instumen penelitian ada dua cara yaitu validisi ahli dan validasi konstruk. Validasi ahli oleh dua orang ahli, Dr. Kokom Komariah dan Dr. Widji. Dr. Kokom Komariah adalah dosen Tata Boga Universitas Negeri Yogyakarta mengampu mata kuliah Managemen Menu dan Dr. Widji adalah dosen Tata Busana Universitas Negeri Yogyakarta mengampu mata kuliah Analisis Fashion.
Setelah direvisi sesuai saran ahli, instrumen penelitian ini dinyatakan telah layak akan digunakan uji coba secara empiris di lapangan.

Hasil validasi konstruk Setelah instrumen divalidasiberdasarkan pertimbangan para ahli, selanjutnya dilakukan validasi konstrak dengan menguji coba instrumen secara empiris pada sampel dari populasi yaitu sebanyak 50 orang (Sugiyono, 2012: 354).

Sampel yang digunakan untuk ujicoba instrumen bukan sampel yang digunakan untuk penelitian. Sampel diambil secara proporsional acak. Semua sampel yang digunakan untuk uji coba instrumen berasal dari SMK Negeri Dlanggu sebanyak 50 orang. Hasil uji coba instrumen kemudian dianalisis.Data ujicoba instrumen dapat dilihat pada lampiran 4 sampai dengan lampiran 7 .

Setelah perolehan data melalui uji coba instrumen secara empiris, selanjutnya untuk mengetahui item-item dalam instrumen itu valid, maka digunakan teknis korelasi product moment dari Carl Pearson menggunakan software SPSS 18 untuk instrumen angket. Pengambilan keputusan berdasarkan nilai probabilitas sig. (2-tailed) dan penjelasan tanda bintang $(* / * *)$ pada korela pearson (Hartono, 2010: 58). Apabilasig. (2-tailed) < 0,05 dan terdapat tanda bintang $(* / * *)$ pada nilai korelasi berarti item tersebut valid.

Hasil pengukuran dengan menggunakan SPSS menunjukkan bahwa pada variabel strategi pembelajaran, gaya belajar siswa, sarana praktik, dan media pembelajaran semua item valid. Sehingga instrumen ini bisa digunakan untuk mengambil data penelitian.

Reliabilitas insrument menggunakan formula Cronbach's Alpha. Menurut Feldt dan Brennan (dalam Mardapi, 2007: 125), bahwa indeks kehandalan tes lebih besar dari 0,70 maka sudah dapat diterima.

Hasil analisis yang dilakukan dengan bantuan software SPPS 18 menunjukkan bahwa instrumen keempat variabel penelitian, yaitu strategi pembelajaran (koefisien Alfa $=0,963$ ), gaya belajar siswa (koefisien Alfa $=0,972)$, sarana praktik ((koefisien Alfa $=$ 0,926), dan media pembelajaran (koefisien Alfa $=0,961)$ termasuk baik. Hal ini terlihat dari koefisien alpha yang lebih besar dari 0,70. 


\section{Teknik Analisa Data}

Teknik analisis data dalam penelitian ini menggunakan dan analisis regresi. Analisis regresi merupakan teknik analisis data untuk membuat keputusan apakah naik turunnya variabel dependen terjadi karena peningkatan variable independen atau tidak. Analisis regresi yang digunakan dalam penelitian ini adalah analisis regresi linier sederhana dan analisis regresi linier ganda.

Analisis regresi sederhana digunakan apabila peneliti ingin meramalkan bagaimana pengaruh antara 1 variabel independen terhadap variabel dependen sedangkan analisis regresi ganda digunakan apabila peneliti ingin meramalkan bagaimana keadaan variable dependen bila 2 atau lebih variabel independen sebagai faktor prediktor dimanipulasi. Karena dalam penelitian ini terdapat 4 variabel independen maka teknik analisis regresi ganda juga digunakan untuk mengetahui pengaruh variabel independen secara bersama-sama terhadap variabel dependen.

\section{HASIL PENELITIAN DAN PEMBAHASAN}

\section{Deskripsi Data}

Berdasarkan data yang telah diperoleh, maka dilakukan analisis terhadap datadata tersebut sehingga dapat menjawab permasalahan-permasalahan yang ada. Adapun rincian hasil olah data adalah sebagai berikut.

\section{Strategi Pembelajaran}

Berdasarkan hasil analisa data menunjukkan bahwa variabel strategi pembelajaran diperoleh skor tertinggi yang dicapai siswa sebesar 98, skor terendah sebesar 32. Dari hasil perhitungan statistik diperoleh rerata/mean (M) sebesar 62,86, Medium sebesar 63, Mode (Mo) sebesar 65, dan standar deviasi (SD) sebesar 13,55. Secara ideal skor terendah 21 dan skor tertinggi 105 sehingga didapatkan mean ideal (Mi) sebesar 63 dan standar deviasi (SDi) sebesar 14. Analisa deksriptif variabel strategi pembelajaran dapat dilihat pada lampiran 17. Distribusi frekuensi variabel data strategi pembelajaran dapat dilihat pada tabel 7 .
Tabel 7. Distribusi Frekuensi Data Variabel Strategi Pembelajaran

\begin{tabular}{lccc}
\hline Kategori & $\begin{array}{c}\text { Rentang } \\
\text { Skor }\end{array}$ & Frek & (\%) \\
\hline Sangat Tinggi & $84<\mathrm{X} \leq 105$ & 19 & 5,64 \\
Tinggi & $77<\mathrm{X} \leq 84$ & 34 & 10,09 \\
Sedang & $56<\mathrm{X} \leq 77$ & 172 & 51,04 \\
Rendah & $42<\mathrm{X} \leq 56$ & 89 & 26,41 \\
Sangat Rendah & $21<\mathrm{X} \leq 42$ & 23 & 6,82 \\
Total & & 337 & 100,00 \\
\hline
\end{tabular}

Berdasarkan tabel 7 di atas, maka dapat digambarkan dalam bentuk histogram seperti gambar 5 .

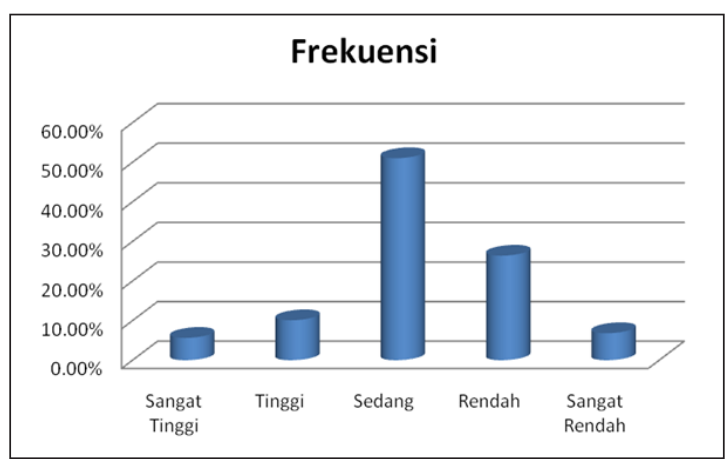

Gambar 5. Histogram Kategori Skor Strategi Pembelajaran

Berdasarkan tabel 7 di atas dapat dideskripsikan bahwa pada variabel strategi pembelajaran dari 337 siswa, 19 siswa atau $5,64 \%$ siswa berpendapat bahwa strategi pembelajaran berpengaruh sangat tinggi, 34 siswa atau $10,09 \%$ siswa berpendapat bahwa strategi pembelajaran berpengaruh tinggi, 172 siswa atau $51,04 \%$ siswa berpendapat bahwa strategi pembelajaran berpengaruh sedang, 89 siswa atau $26,41 \%$ siswa berpendapat bahwa strategi pembelajaran berpengaruh rendah, dan 23 siswa atau 6,82\% berpendapat bahwa strategi pembelajaran berpengaruh sangat rendah. Dari histogram dan tabel distribusi frekuensi data variabel strategi pembelajaran menunjukkan bahwa strategi pembelajaran kompetensi keahlian Tata Boga SMK SeGerbangkertasusila dilihat dari distribusi frekuensi maupun rata-rata termasuk dalam kategori sedang yang ditunjukkan oleh persentase skor tersebut. 


\section{Gaya Belajar}

Berdasarkan hasil analis data menunjukkan bahwa variabel gaya belajar siswa diperoleh skor tertinggi yang dicapai siswa sebesar 111, skor terendah sebesar 49. Dari hasil perhitungan statistik diperoleh rerata/mean (M) sebesar 78,96, Medium sebesar 79, Mode (Mo) sebesar 78, dan standar deviasi (SD) sebesar 12,21. Secara ideal skor terendah 26 dan skor tertinggi 130 sehingga didapatkan mean ideal (Mi) sebesar 78 dan standar deviasi (SDi) sebesar 17,33. Analisa deksriptif variabel gaya belajar dapat dilihat pada lampiran 18 . Distribusi frekuensi variabel data gaya belajar siswa dapat dilihat pada tabel 8 di bawah ini:

Tabel 8. Distribusi Frekuensi Data Variabel Gaya Belajar

\begin{tabular}{lccc}
\hline Kategori & Rentang Skor & Frek & $\mathbf{( \% )}$ \\
\hline Sangat Tinggi & $104<\mathrm{X} \leq 130$ & 5 & 1,48 \\
Tinggi & $95,33<\mathrm{X} \leq 104$ & 30 & 8,90 \\
Sedang & $69,33<\mathrm{X} \leq 95,33$ & 221 & 65,58 \\
Rendah & $52<\mathrm{X} \leq 69,33$ & 77 & 22,85 \\
Sangat Rendah & $26<\mathrm{X} \leq 52$ & 4 & 1,19 \\
Total & & 337 & 100,00 \\
\hline
\end{tabular}

Berdasarkan tabel 8 di atas, maka dapat digambarkan dalam bentuk histogram seperti di bawah ini.

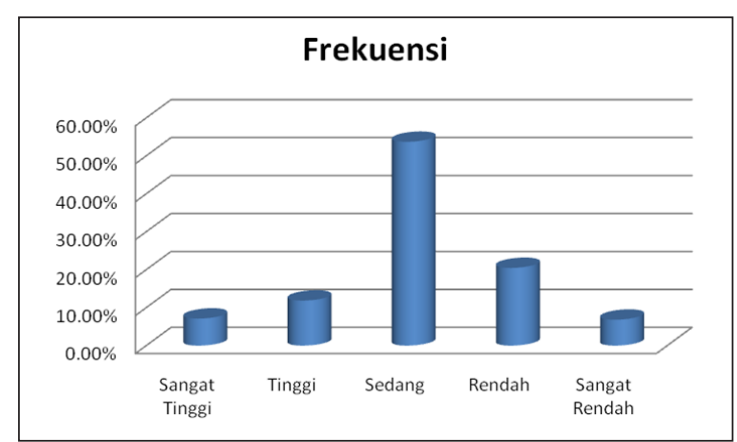

Gambar 6. Histogram Kategori Skor Gaya Belajar

Berdasarkan tabel 8 di atas dapat dideskripsikan bahwa pada variabel gaya belajar siswa dari 337 siswa, 5 siswa atau 1,48\% siswa memiliki gaya belajar berkategori sangat tinggi, 30 siswa atau $8,90 \%$ siswa memiliki gaya belajar kategori tinggi, 221 siswa atau 65,58\% siswa memiliki gaya belajar kategori sedang, 77 siswa atau $22,85 \%$ siswa memiliki gaya belajar kategori rendah, dan 4 siswa atau 1,19\% siswa memiliki gaya belajar kategori sangat rendah. Dari histogram dan tabel distribusi frekuensi data variabel gaya belajar menunjukkan bahwa gaya belajar kompetensi keahlian Tata Boga SMK Se-Gerbangkertosusilo dilihat dari distribusi frekuensi maupun rata-rata termasuk dalam kategori sedang yang ditunjukkan oleh persentase skor tersebut.

\section{Sarana Praktik}

Berdasarkan hasil analis data (lampiran 16) menunjukkan bahwa variabel sarana praktik diperoleh skor tertinggi yang dicapai siswa sebesar 46, skor terendah sebesar 15. Dari hasil perhitungan statistik diperoleh rerata/ mean (M) sebesar 30,69, Medium sebesar 31, Mode (Mo) sebesar 30,00, dan standar deviasi (SD) sebesar 6,61. Secara ideal skor terendah 10 dan skor tertinggi 50 sehingga didapatkan mean ideal (Mi) sebesar 30 dan standar deviasi (SDi) sebesar 6,67. Analisa deksriptif variabel sarana praktik dapat dilihat pada lampiran 16. Distribusi frekuensi variabel data sarana praktik dapat dilihat pada tabel 9.

Tabel 9. Distribusi Frekuensi Data Variabel Sarana Praktik

\begin{tabular}{lccc}
\hline Kategori & Rentang Skor & Frek & $(\mathbf{\%})$ \\
\hline Sangat Tinggi & $40<\mathrm{X} \leq 50$ & 24 & 7,12 \\
Tinggi & $36,67<\mathrm{X} \leq 40$ & 40 & 11,87 \\
Sedang & $26,67<\mathrm{X} \leq 36,67$ & 181 & 53,71 \\
Rendah & $20<\mathrm{X} \leq 26,67$ & 69 & 20,47 \\
Sangat Rendah & $10<\mathrm{X} \leq 20$ & 23 & 6,82 \\
Total & & 337 & 100,00 \\
\hline
\end{tabular}

Berdasarkan tabel 9 di atas, maka dapat digambarkan dalam bentuk histogram seperti gambar 7.

Berdasarkan tabel 9 di atas dapat dideskripsikan bahwa pada variabel sarana praktik dari 337 siswa, 24 siswa atau 7,12\% siswa berpendapat bahwa sekolah memiliki sarana praktik sangat tinggi, 40 siswa atau $11,87 \%$ siswa berpendapat bahwa sekolah memiliki sarana praktik kategori tinggi, 181 siswa atau $53,71 \%$ siswa berpendapat bahwa sekolah memiliki sarana praktik kategori sedang, 69 siswa atau 20,47\% siswa berpendapat bahwa sekolah memiliki sarana 
praktik kategori rendah, dan 23 siswa atau $6,82 \%$ siswa berpendapat bahwa sekolah memiliki sarana praktik kategori sangat rendah. Dari histogram dan tabel distribusi frekuensi data variabel sarana praktik menunjukkan bahwa sarana praktik kompetensi keahlian Tata Boga SMK Se-Gerbangkertasusila dilihat dari distribusi frekuensi maupun rata-rata termasuk dalam kategori sedang yang ditunjukkan oleh persentase skor tersebut.

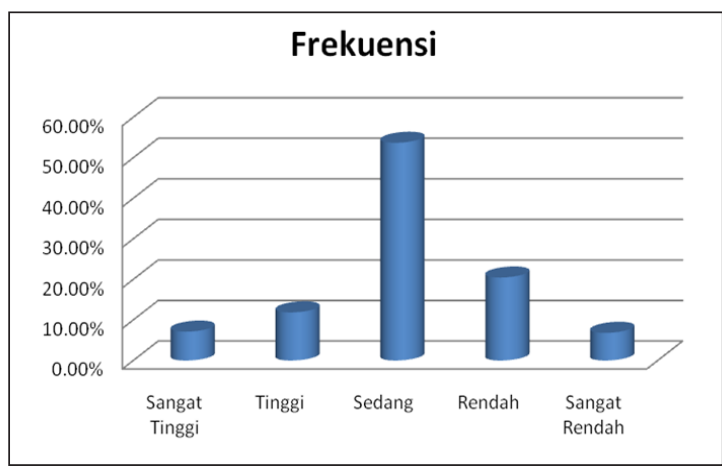

Gambar 7. Histogram Kategori Skor Sarana Praktik

\section{Media Pembelajaran}

Berdasarkan hasil analis data (lampiran 17) menunjukkan bahwa variabel media pembelajarandiperoleh skor tertinggi yang dicapai siswa sebesar 66, skor terendah sebesar 20. Dari hasil perhitungan statistik diperoleh rerata/mean (M) sebesar 44,79, Medium sebesar 45, Mode (Mo) sebesar 47, dan standar deviasi (SD) sebesar 9,80. Secara ideal skor terendah 15 dan skor tertinggi 75 sehingga didapatkan mean ideal (Mi) sebesar 45 dan standar deviasi (SDi) sebesar 10. Analisa deksriptif variabel media pembelajaran dapat dilihat pada lampiran 17. Distribusi frekuensi variabel data media pembelajaran dapat dilihat pada tabel 10 .

Tabel 10. Distribusi Frekuensi Data Variabel Media Pembelajaran

\begin{tabular}{lccc}
\hline Kategori & Rentang Skor & Frek & $\mathbf{( \% )}$ \\
\hline Sangat Tinggi & $60<\mathrm{X} \leq 75$ & 18 & 5,34 \\
Tinggi & $55<\mathrm{X} \leq 60$ & 37 & 10,98 \\
Sedang & $40<\mathrm{X} \leq 55$ & 159 & 47,18 \\
Rendah & $30<\mathrm{X} \leq 40$ & 96 & 28,49 \\
Sangat Rendah & $15<\mathrm{X} \leq 30$ & 27 & 8,01 \\
Total & & 337 & 100,00 \\
\hline
\end{tabular}

Berdasarkan tabel 10 di atas, maka dapat digambarkan dalam bentuk histogram seperti di bawah ini.

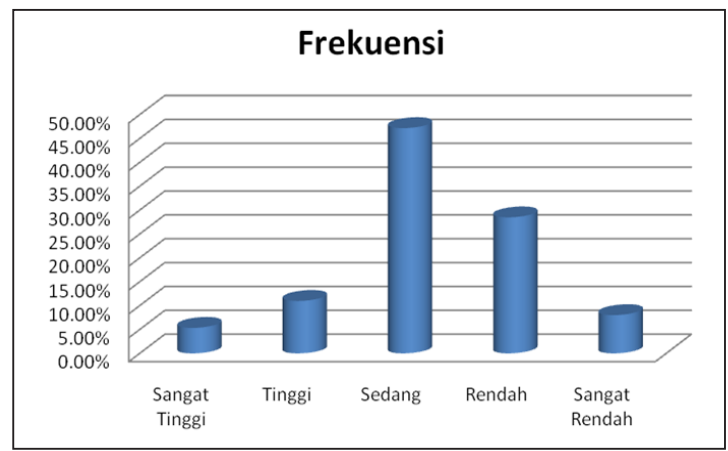

Gambar 8. Histogram Kategori Skor Media Pembelajaran

Berdasarkan tabel 10 di atas dapat dideskripsikan bahwa pada variabel media pembelajaran dari 337 siswa, 18 siswa atau $5,34 \%$ siswa berpendapat bahwa guru menggunakan media pembelajaran sangat tinggi, 37 siswa atau $10,89 \%$ siswa berpendapat bahwa guru menggunakan media pembelajaran kategori tinggi, 159 siswa atau $47,18 \%$ siswa berpendapat bahwa guru menggunakan media pembelajaran kategori sedang, 96 siswa atau $28,49 \%$ siswa berpendapat bahwa guru menggunakan media pembelajaran kategori rendah, dan 27 siswa atau $8,01 \%$ siswa berpendapat bahwa guru menggunakan media pembelajaran kategori sangat rendah. Dari histogram dan tabel distribusi frekuensi data variabel media pembelajaran menunjukkan bahwa media pembelajaran kompetensi keahlian Tata Boga SMK Se-Gerbangkertasusila dilihat dari distribusi frekuensi maupun rata-rata termasuk dalam kategori sedang yang ditunjukkan oleh persentase skor tersebut.

\section{Hasil Belajar Patiseri}

Berdasarkan hasil analis data menunjukkan bahwa variabel hasil belajar patiseri diperoleh skor tertinggi yang dicapai siswa sebesar 92, skor terendah sebesar 70. Dari hasil perhitungan statistik diperoleh rerata/mean (M) sebesar 78,05, Medium sebesar 78, Mode (Mo) sebesar 70, dan standar deviasi (SD) sebesar 6,16. Secara ideal skor terendah 0 dan skor tertinggi 100 sehingga didapatkan mean ideal (Mi) sebesar 50 dan standar deviasi (SDi) 
sebesar 16,67. Analisa deksriptif variabel hasil belajar patiseri dapat dilihat pada lampiran 18 . Distribusi frekuensi variabel data hasil belajar patiseri dapat dilihat pada tabel 11 di bawah ini:

Tabel 11. Distribusi Frekuensi Data Variabel Hasil Belajar Patiseri

\begin{tabular}{lccc}
\hline Kategori & Rentang Skor & Frek & (\%) \\
\hline Sangat Tinggi & $75<\mathrm{X} \leq 100$ & 210 & 62,31 \\
Tinggi & $66,67<\mathrm{X} \leq 75$ & 127 & 37,69 \\
Sedang & $41,67<\mathrm{X} \leq 66,67$ & 0 & 0 \\
Rendah & $25<\mathrm{X} \leq 41,67$ & 0 & 0 \\
Sangat Rendah & $0<\mathrm{X} \leq 25$ & 0 & 0 \\
Total & & 337 & 100,00 \\
\hline
\end{tabular}

Berdasarkan tabel 11 di atas, maka dapat digambarkan dalam bentuk histogram seperti 9 .

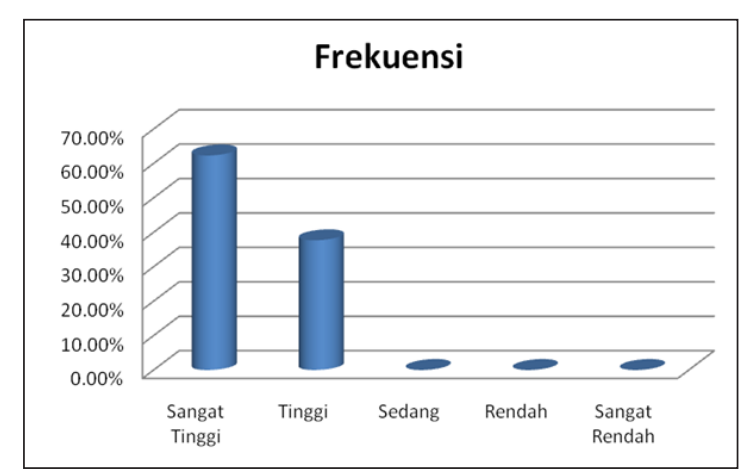

Gambar 9. Histogram Kategori Skor Hasil Belajar Patiseri

Berdasarkan tabel 11 di atas dapat dideskripsikan bahwa pada variabel hasil belajar patiseri dari 337 siswa, 210 siswa atau $62,31 \%$ siswa memiliki hasil belajar patiseri sangat tinggi, 127 siswa atau $37,69 \%$ siswa memiliki hasil belajar patiseri kategori tinggi, dan tidak ada siswa yang memiliki hasil belajar patiseri berkategori sedang, rendah, dan sangat rendah. Dari histogram dan tabel distribusi frekuensi data variabel hasil belajar patiseri menunjukkan bahwa hasil belajar patiseri kompetensi keahlian Tata Boga SMK Se-Gerbangkertasusila dilihat dari distribusi frekuensi maupun rata-rata termasuk dalam kategori sangat tinggi yang ditunjukkan oleh persentase skor tersebut.

\section{Uji Prasyarat Analisis}

Hasil pengujian persyaratan teknik analisis regresi ganda diuraikan sebagai berikut.

\section{Uji Normalitas}

Uji normalitas dapat dilakukan untuk mengetahui kondisi masing-masing variabel penelitian, apakah data berdistribusi normal atau tidak. Uji normalitas data dalam penelitian ini dilakukan dengan menggunakan Uji Kolmorogorov-Smirnov, dengan berpedoman pengambilan keputusan jika nilai asym. Sig.> 0.05 maka data terdistribusi normal, sebaliknya jika nilai asymp. Sig. $<0.05$, maka data tidak terdistribusi dengan normal.

Variabel strategi pembelajaran $\left(\mathrm{X}_{1}\right)$ memiliki nilai asymp. Sig. (p) sebesar 0,408; gaya belajar $\left(\mathrm{X}_{2}\right)$ memiliki nilai asymp. Sig. (p) sebesar 0,579; sarana praktik $\left(\mathrm{X}_{3}\right)$ memiliki nilai asymp. Sig. (p) sebesar 0,268; media pembelajaran $\left(\mathrm{X}_{4}\right)$ memiliki nilai asymp. Sig. (p) sebesar 0,313 dan hasil belajar Patiseri (Y) memiliki nilai asymp. Sig. (p) sebesar 0,060. Dengan demikian dapat disimpulkan bahwa data strategi pembelajaran, gaya belajar, sarana praktik, media pembelajaran dan hasil belajar Patiseri terdistribusi normal.

\section{Uji Linieritas}

Uji linieritas dilakukan untuk mengetahui apakah data masing-masing variabel bebas mempunyai hubungan yang linier dengan variabel terikat. Perdoman yang digunakan untuk menentukan kelinieran adalah dengan melihat hasil analisis pada lajur deviation from linearity. Ketentuan yang digunakan untuk pengambilan keputusan adalah jika nilai signifikansi pada deviation from linearity $>$ 0.05 , maka disimpulkan hubungan variabel bebas dengan variabel terikat linier, sebaliknya jika nilai signifikansi pada deviation from linearity< 0.05 , maka disimpulkan hubungan variabel bebas dengan variabel terikat tidak linier.

Hasil uji linieritas dnegan menggunakan program SPSS versi 18 for windows, menunjukkan bahwa hubungan antara variabel bebas strategi pembelajaran $\left(\mathrm{X}_{1}\right)$, gaya belajar $\left(\mathrm{X}_{2}\right)$, sarana praktik $\left(\mathrm{X}_{3}\right)$, dan media 
pembelajaran $\left(\mathrm{X}_{4}\right)$ terhadap hasil belajar Patiseri (Y) mempunyai hubungan yang linier.

\section{Uji Multikolinieritas}

Uji multikolinieritas dilakukan untuk mengetahui besarnya harga interkorelasi antara sesama variabel bebas. Uji multikolinieritas berhubungan dengan variabel penelitian yang saling bebas dan ada tidaknya variabel yang yang tergantung pada variabel lain. Perhitungan interkorelasi antara variabel bebas dapat diketahui dari koefisien korelasi antara variabel bebas. Suatu variabel bebas yang memiliki $\mathrm{F}$ lebih kecil dari 10 dapat disimpulkan tidak terjadi multikolinieritas.

Variabel strategi pembelajaran $\left(\mathrm{X}_{1}\right)$ mempunyai nilai VIF sebesar 3,475, variabel gaya belajar $\left(\mathrm{X}_{2}\right)$ mempunyai nilai VIF sebesar 3,075 , variabel sarana praktik $\left(X_{3}\right)$ mempunyai nilai VIF sebesar 1,198 , dan variabel media pembelajaran mempunyai nilai VIF sebesar 2,826. Dengan berpedoman pada ketentuan VIF $<10$ maka dapat disimpulkan bahwa tidak terjadi multikolinieritas antara keempat variabel bebas strategi pembelajaran, gaya belajar, sarana praktik, dan media pembelajaran.

\section{Uji Hipotesis}

\section{Hipotesis pertama}

Hipotesis pertama, strategi pembelajaran mempunyai pengaruh positif dan signifikan terhadap hasil belajar Patiseri SMK SeGerbangkertasusila Kompetensi Keahlian Tata Boga.

Hasil analisis regresi linier ganda yang menunjukkan koefisien untuk strategi pembelajaran $\left(\mathrm{X}_{1}\right)$ adalah 0,596 yang bernilai positif. Berarti hasil belajar patiseri akan meningkat apabila strategi pembelajaran ditingkatkan. Semakin tinggi strategi pembelajaran, maka semakin tinggi hasil belajar patiseri. Nilai probabilitas pada kolom Sig. adalah 0,000 , nilai $p<0,05$ dapat diartikan bahwa pengaruh strategi pembelajaran terhadap hasil belajar patiseri adalah signifikan. Sehingga dari hasil analisis regresi ganda dapat disimpulkan bahwa strategi pembelajaran memberi pengaruh positif dan signifikansi terhadap hasil belajar patiseri. Dengan demikian hipotesis pertama yang menyatakan strategi pembelajaran mempunyai pengaruh positif dan signifikan terhadap hasil belajar Patiseri SMK Se-Gerbangkertasusila Kompetensi Keahlian Tata Boga terbukti.

Korelasi kontribusi strategi pembelajaran terhadap hasil belajar patiseri dapat diketahui dari hasil teknik analisis regresi linier sederhana antara variabel strategi pembelajaran terhadap hasil belajar patiseri adalah 0,735 . Dengan demikian berarti terdapat tingkat hubungan yang kuat antara strategi pembelajaran dengan hasil belajar patiseri. Berdasarkan tabel 16 juga diperoleh koefisien determinasi $\left(\mathrm{R}^{2}\right)$ yaitu 0,540 . Hal ini berarti kontribusi strategi pembelajaran terhadap hasil belajar patiseri sebesar 54\%, sedangkan 46\% dipengaruhi oleh variabel lainnya.

\section{Hipotesis kedua}

Hipotesis kedua, gaya belajar siswa mempunyai pengaruh positif dan signifikan terhadap hasil belajar patiseri siswa SMK SeGerbangkertasusila Kompetensi Keahlian Tata Boga. Hipotesis ini untuk melihat pengaruh gaya belajar siswa terhadap hasil belajar patiseri.

Hasil analisis regresi ganda yang menunjukkan koefisien untuk gaya belajar siswa $\left(\mathrm{X}_{2}\right)$ adalah 0,414 yang bernilai positif. Berarti hasil belajar patiseri akan meningkat apabila gaya belajar siswa ditingkatkan. Semakin tinggi gaya belajar siswa, maka semakin tinggi hasil belajar siswa patiseri. Nilai probabilitas pada kolom Sig. adalah 0,000 , nilai $p<0.05$ dapat diartikan bahwa pengaruh gaya belajar siswa terhadap hasil belajar patiseri adalah signifikan. Sehingga dari hasil analisis regresi ganda dapat disimpulkan bahwa gaya belajar siswa memberi pengaruh positif dan signifikansi terhadap hasil belajar siswa patiseri. Dengan demikian hipotesis pertama yang menyatakan gaya belajar siswa mempunyai pengaruh positif dan signifikan terhadap hasil belajar patiseri siswa SMK SeGerbangkertasusila terbukti.

Korelasi kontribusi gaya belajar siswa terhadap hasil belajar patiseri dapat diketahui dari hasil teknik analisis regresi linier sederhana gaya belajar siswa terhadap hasil belajar adalah 0,567. Dengan demikian berarti terdapat tingkat hubungan yang sedang 
antara gaya belajar siswa dengan hasil belajar patiseri. Berdasarkan tabel 4.11 juga diperoleh koefisien determinasi $\left(\mathrm{R}^{2}\right)$ yaitu 0,321 . Hal ini berarti kontribusi gaya belajar siswa terhadap hasil belajar patiseri sebesar $32,1 \%$, sedangkan $67,9 \%$ dipengaruhi oleh variabel lainnya.

\section{Hipotesis ketiga}

Hipotesis pertama, sarana praktik mempunyai pengaruh positif dan signifikan terhadap hasil belajar patiseri siswa SMK SeGerbangkertasusila Kompetensi Keahlian Tata Boga. Hipotesis ini untuk melihat pengaruh sarana praktik terhadap hasil belajar patiseri.

Hasil analisis regresi ganda yang menunjukkan koefisien untuk sarana praktik $\left(\mathrm{X}_{3}\right)$ adalah 0,551 yang bernilai positif. Berarti hasil belajar akan patiseri meningkat apabila sarana praktik ditingkatkan. Semakin tinggi sarana praktik, maka semakin tinggi hasil belajar siswa patiseri. Nilai probabilitas pada kolom Sig. adalah 0,002, nilai $p<0.05$ dapat diartikan bahwa pengaruh sarana praktik terhadap hasil belajar patiseri adalah signifikan. Sehingga dari hasil analisis regresi ganda dapat disimpulkan bahwa partisipasi memberi pengaruh positif dan signifikansi terhadap hasil belajar patiseri. Dengan demikian hipotesis pertama yang menyatakan sarana praktik mempunyai pengaruh positif dan signifikan terhadap hasil belajar patiseri siswa SMK SeGerbangkertasusila terbukti.

Korelasi kontribusi sarana praktik terhadap hasil belajar dapat diketahui dari hasil teknik analisis regresi sederhana sarana praktik terhadap hasil belajar patiseri adalah 0,222 . Dengan demikian berarti terdapat tingkat hubungan yang kuat antara sarana praktik dengan hasil belajar patiseri. Berdasarkan tabel 20 juga diperoleh koefisien determinasi $\left(\mathrm{R}^{2}\right)$ yaitu 0,490 . Hal ini berarti kontribusi sarana praktik terhadap hasil belajar patiseri sebesar 49\%, sedangkan 51\% dipengaruhi oleh variabel lainnya.

\section{Hipotesis keempat}

Hipotesis keempat, media pembelajaran mempunyai pengaruh positif dan signifikan terhadap hasil belajar Patiseri SMK SeGerbangkertasusila Kompetensi Keahlian Tata Boga. Hipotesis ini untuk melihat pengaruh media pembelajaran terhadap hasil belajar Patiseri.

Hasil analisis regresi linier ganda yang menunjukkan koefisien untuk media pembelajaran $\left(\mathrm{X}_{4}\right)$ adalah 0,617 yang bernilai positif. Berarti hasil belajar patiseri akan meningkat apabila media pembelajaran ditingkatkan. Semakin tinggi media pembelajaran, maka semakin tinggi hasil belajar patiseri. Nilai probabilitas pada kolom Sig. adalah 0,000 , nilai $p<0.05$ dapat diartikan bahwa pengaruh media pembelajaran terhadap hasil belajar patiseri adalah signifikan. Sehingga dari hasil analisis regresi ganda dapat disimpulkan bahwa media pembelajaran memberi pengaruh positif dan signifikansi terhadap hasil belajar patiseri. Dengan demikian hipotesis pertama yang menyatakan media pembelajaran mempunyai pengaruh positif dan signifikan terhadap hasil belajar Patiseri SMK Se-Gerbangkertasusila Kompetensi Keahlian Tata Boga terbukti.

Korelasi kontribusi media pembelajaran terhadap hasil belajar patiseri dapat diketahui dari hasil teknik analisis regresi linier sederhana antara variabel media pembelajaran terhadap hasil belajar patiseri adalah 0,735 . Dengan demikian berarti terdapat tingkat hubungan yang kuat antara media pembelajaran dengan hasil belajar patiseri. Berdasarkan tabel 22 juga diperoleh koefisien determinasi $\left(\mathrm{R}^{2}\right)$ yaitu 0,540 . Hal ini berarti kontribusi media pembelajaran terhadap hasil belajar patiseri sebesar 54\%, sedangkan $46 \%$ dipengaruhi oleh variabel lainnya.

\section{Hipotesis kelima}

Hipotesis kelima, strategi pembelajaran, gaya belajar siswa, sarana praktik, dan media pembelajaran secara bersama-sama mempunyai pengaruh positif dan signifikan terhadap hasil belajar patiseri siswa SMK SeGerbangkertasusila Kompetensi Keahlian Tata Boga. Hipotesis ini untuk melihat pengaruh strategi pembelajaran, gaya belajar siswa, sarana praktik, dan media pembelajaran secara bersama-sama terhadap hasil belajar patiseri.

Hasil analisis regresi ganda yang menunjukkan koefisien untuk strategi pembelajaran $\left(\mathrm{X}_{1}\right)$, gaya belajar siswa $\left(\mathrm{X}_{2}\right)$, 
sarana praktik $\left(\mathrm{X}_{3}\right)$, dan media pembelajaran $\left(\mathrm{X}_{4}\right)$ secara bersama-sama adalah 0,749 yang bernilai positif. Berarti hasil belajar patiseri akan meningkat apabila strategi pembelajaran, gaya belajar siswa, sarana praktik, dan media pembelajaran secara bersama-sama ditingkatkan. Semakin tinggi strategi pembelajaran, gaya belajar siswa, sarana praktik, dan media pembelajaran secara bersama-sama, maka semakin tinggi hasil belajar siswa patiseri. Nilai probabilitas pada kolom Sig. adalah 0,000, nilai $p<0.05$ dapat diartikan bahwa pengaruh strategi pembelajaran, gaya belajar siswa, sarana praktik, dan media pembelajaran secara bersama-sama terhadap hasil belajar patiseri adalah signifikan. Sehingga dari hasil analisis regresi ganda dapat disimpulkan bahwa strategi pembelajaran, gaya belajar siswa, sarana praktik, dan media pembelajaran secara bersama-sama memberi pengaruh positif dan signifikansi terhadap hasil belajar siswa patiseri. Dengan demikian hipotesis keempat yang menyatakan strategi pembelajaran, gaya belajar siswa, sarana praktik, dan media pembelajaran secara bersama-sama mempunyai pengaruh positif dan signifikan terhadap hasil belajar patiseri siswa SMK SeGerbangkertasusila terbukti.

Hasi perhitungan koefisien determinasi $\left(\mathrm{R}^{2}\right)$ sebesar 0,560 . Hal ini berarti kontribusi strategi pembelajaran, gaya belajar siswa, sarana praktik, dan media pembelajaran secara bersama-sama terhadap hasil belajar patiseri sebesar 56\%, sedangkan $44 \%$ dipengaruhi oleh variabel lainnya.

\section{Pembahasan}

Penelitian ini bertujuan untuk mengetahui pengaruh strategi pembelajaran, gaya belajar siswa, sarana praktik, dan media pembelajaran terhadap hasil belajar patiseri di SMK SeGerbangkertasusila Kompetensi Keahlian Tata Boga.

Pengaruh strategi pembelajaran terhadap hasil belajar patiseri di SMK SeGerbangkertasusila

Secara deskriptif, hasil penelitian ini mengungkapkan bahwa tentang pengaruh strategi pembelajaran terhadap hasil belajar patiseri di SMK Se-Gerbangkertasusila. Berdasarkan tingkat kecenderungannya, strategi pembelajaran siswa memiliki kategori sangat tinggi sebesar 5,64\% (19 siswa), kategori tinggi 10,09\% (34 siswa), kategori sedang 51,04\% (172 siswa), kategori rendah 26,41\% (89 siswa), dan kategori sangat rendah $6,82 \%$ (23 siswa). Adapun distribusi frekuensi variabel strategi pembelajaran siswa dapat dilihat pada tabel 19 Kemudian sesuai coefficient yang dapat dilihat pada tabel30, maka persamaan regresi untuk X1 terhadap Y adalah:

$$
\mathrm{Y}=0,596 \mathrm{X} 1+72,024
$$

dari pesamaan regresi di atas, diharapkan setiap kenaikan 1 poin strategi pembelajaran, hasil belajar patiseri naik sebesar 0,596 poin. Strategi pembelajaran patiseri menggunakan model Work-orientedlearning (pembelajaran berorientasi kerja). Strategi pembelajaran ini adalah pembelajaran berorientasi kerja terjadipada satu tempat atau lokasi, misalnya kejuruan perguruan tinggi dan pusat pelatihan kejuruan. Dalam beberapa kasus, strategi ini memerlukan pembelajaran dalam melaksanakan pekerjaan yang ditugaskan di lingkungan yang sangat mirip dengan situasi kehidupan nyata kerja. Tetapi, tentu saja, pembelajarannya adalah kegiatan yang terencana dan terorganisir.

\section{Pengaruh gaya belajar terhadap hasil belajar patiseri di SMK Se-Gerbangkertasusila}

Secara deskriptif, hasil penelitian ini mengungkapkan bahwa tentang pengaruh gaya belajar siswa terhadap hasil belajar patiseri di SMK Se-Gerbangkertasusila. Berdasarkan tingkat kecenderungannya, gaya belajar siswa memiliki kategori sangat tinggi sebesar 1,48\% (5 siswa), kategori tinggi 8,90\% (30 siswa), kategori sedang 65,58\% (221 siswa), kategori rendah $22,85 \%$ (77 siswa), dan kategori sangat rendah 1,19\% (4 siswa). Adapun distribusi frekuensi variabel gaya belajar siswa dapat dilihat pada tabel 20. Kemudian sesuai coefficient yang dapat dilihat pada tabel 31 , maka persamaan regresi untuk $\mathrm{X}_{2}$ terhadap $\mathrm{Y}$ adalah:

$$
Y=0,414 X_{2}+69,055
$$


dari pesamaan regresi di atas, diharapkan setiap kenaikan 1 poin gaya belajar, hasil belajar patiseri naik sebesar 0,414 poin.

Gaya belajar adalah kunci untuk mengembangkan kinerja dalam pekerjaan, disekolah, dan dalam situasi antar pribadi. Di beberapa sekolah dasar dan lanjutan di Amerika, para guru menyadari bahwa setiap orang mempunyai cara yang optimal formasi baru. Mereka memahami bahwa beberapa murid perlu di ajarkan cara-cara yang lain dari metode mengajar standar. Jika muridmurid ini diajar dengan metodestandar,kemu ngkinankecilmerekadapatmemahamiapa yang dibeikan. Mengetahui gaya belajar yangbebeda initelahmembantu para gurudimanapun untuk dapat mendekati semua atau hamper semua murid hanya dengan menyampaikna informasi dengan gaya yang berbeda-beda.

\section{Pengaruh sarana praktik terhadap hasil belajarpatiseridiSMKSe-Gerbangkertasusila}

Secara deskriptif, hasil penelitian ini mengungkapkan bahwa tentang pengaruh sarana praktik terhadap hasil belajar patiseri di SMK Se-Gerbangkertasusila. Berdasarkan tingkat kecenderungannya, sarana praktik memiliki kategori sangat tinggi sebesar 7,12\% (24 siswa), kategori tinggi 11,87\% (40 siswa), kategori sedang 53,71\% (181 siswa), kategori rendah 20,47\% (69 siswa), dan kategori sangat rendah 6,82\% (23 siswa). Adapun distribusi frekuensi variabel sarana praktik dapat dilihat pada tabel 21. Kemudian sesuai coefficient yang dapat dilihat pada tabel22, maka persamaan regresi untuk $\mathrm{X}_{3}$ terhadap $\mathrm{Y}$ adalah:

$$
\mathrm{Y}=0,551 \mathrm{X}_{3}+73,293
$$

dari pesamaan regresi di atas, diharapkan setiap kenaikan 1 poin tingkat sarana praktik, hasil belajar patiseri naik sebesar 0,551 poin.

Patiseri merupakan salah satu pengetahuan dalam pengolahan dan penyajian makanan, khususnya mengolah dan menyajikan berbagai jenis kue. Untuk mendapatkan hasil olahan kue yang baik maka peralatan yang digunakan sangat menentukan baik mutu bahan alat, ukuran alat, maupun kebersihan alatnya. Peralatan yang dipergunakan dalam patiseri sangatlah banyak ragam dan fungsinya.
Peralatan patiseri ada yang besar atau berat dan peralatan yang kecil atau ringan ada juga peralatan untuk mengukur, mencampur, pemotong, pengembang, memasak, dan mendekor. Peralatan ini sama berartinya dalam penggunaan, kebersihan harus selalu terjaga dan siap pakai setiap saat.

\section{Pengaruh media pembelajaran terhadap hasil belajar patiseridiSMKSe-Gerbangkertasusila}

Secara deskriptif, hasil penelitian ini mengungkapkan bahwa tentang pengaruh media pembelajaran terhadap hasil belajar patiseri di SMK Se-Gerbangkertasusila. Berdasarkan tingkat kecenderungannya, media pembelajaran siswa memiliki kategori sangat tinggi sebesar 5,34\% (18 siswa), kategori tinggi 10,98\% (37 siswa), kategori sedang 47,18\% (159 siswa), kategori rendah 28,49\% (96 siswa), dan kategori sangat rendah 8,01\% (27 siswa). Adapun distribusi frekuensi variabel strategi pembelajaran siswa dapat dilihat pada tabel 22 Kemudian sesuai coefficient yang dapat dilihat pada tabel23, maka persamaan regresi untuk $\mathrm{X}_{4}$ terhadap $\mathrm{Y}$ adalah:

$$
\mathrm{Y}=0,617 \mathrm{X}_{4}+72,347
$$

dari pesamaan regresi di atas, diharapkan setiap kenaikan 1 poin strategi pembelajaran, hasil belajar patiseri naik sebesar 0,617 poin.

Penggunaan media dalam pembelajaran dapat membantu anak dalam memberikan pengalaman yang bermakna bagi peserta didik. Penggunaan media dalam pembelajaran dapat mempermudah peserta didik dalam memahami sesuatu yang abstrak menjadi lebih konkrit. Halini sesuai dengan pendapat Jerome $\mathrm{S}$ Bruner bahwa peserta didik belajar melaluitiga tahapan yaitu enaktif, ikonik, dan simbolik.Tahap enaktif yaitu tahap dimana peserta didik belajar dengan memanipulasi benda-benda konkrit. Tahap ikonik yaitu suatu tahap dimanapeserta didik belajar dengan menggunakan gambar atau videotapes. Sementara tahap simbolik yaitu tahap dimanape serta didik belajar dengan menggunakan simbol-simbol.

Pengaruh strategi pembelajaran, gaya belajar, sarana praktik, dan media pembelajaran terhadap hasil belajar patiseri di SMK SeGerbang kertasusila 
Hasil penelitian ini mengungkapkan bahwa strategi pembelajaran $\left(\mathrm{X}_{1}\right)$, gaya belajar siswa $\left(\mathrm{X}_{2}\right)$, sarana praktik $\left(\mathrm{X}_{3}\right)$, media pembelajaran $\left(\mathrm{X}_{4}\right)$ terhadap hasil belajar patiseri $(\mathrm{Y})$, dengan menggunakan regresi ganda didapat harga $R$ Square sebesar 0,560 (lihat tabel 23). Artinya strategi pembelajaran, gaya belajar siswa, sarana praktik, dan media pembelajaran secara bersama-sama memiliki pengaruh terhadap hasil belajar patiseri sebesar 56\%. Sedangkan $46 \%$ lainnya dipengaruhi oleh variabel lainnya yang tidak diteliti dalam penelitian ini.

Untuk coefficient dapat dilihat pada lampiran 34, maka persamaan garis regresi ganda untuk $\mathrm{X}_{1}, \mathrm{X}_{2}, \mathrm{X}_{3}$, dan $\mathrm{X}_{4}$ terhadap $\mathrm{Y}$ adalah:

$$
\begin{gathered}
\mathrm{Y}=0,596 \mathrm{X}_{1}+0,0,036 \mathrm{X}_{2}+0,109 \mathrm{X}_{3}+0,617 \\
\mathrm{X}_{4}+67,547
\end{gathered}
$$

Keempat komponen, yaitu strategi pembelajaran, gaya belajar, sarana praktik, dan media pembelajaran mempengaruh hasil belajar patiseri di SMK Se-Gerbangkertasusila.

\section{SIMPULAN DAN SARAN}

\section{Simpulan}

Berdasarkan rumusan masalah dan pengujian hipotesis yang telah dilakukan, maka diambil simpulan sebagai berikut.

Terdapat pengaruh positif dan signifikan antara strategi pembelajaran terhadap hasil belajar patiseri pada siswa Program Keahlian Tata Boga SMK Se-Gerbangkertasusila $\left(\mathrm{r}_{\mathrm{x} 1 \mathrm{y}}\right.$ $=0,735 ; p<0,05)$. Dari analisis tersebut strategi pembelajaran memberikan sumbangan terhadap hasil belajar patiseri sebesar 54\% ( $\mathrm{R}^{2}$ $=0,540$ ).

Terdapat pengaruh positif dan signifikan antara gaya belajar siswa terhadap hasil belajar patiseri pada siswa Program Keahlian Tata Boga SMK Se-Gerbangkertasusila $\left(\mathrm{r}_{\mathrm{x} 2 \mathrm{y}}=0,567 ; p<\right.$ $0,05)$. Dari analisis tersebut gaya belajar siswa memberikan sumbangan terhadap hasil belajar patiseri sebesar $32,1 \%\left(\mathrm{R}^{2}=0,321\right)$.

Terdapat pengaruh positif dan signifikan antara sarana praktik terhadap hasil belajar patiseri pada siswa Program Keahlian Tata Boga SMK Se-Gerbangkertasusila $\left(\mathrm{r}_{\mathrm{x} 3 \mathrm{y}}=\right.$
0,222; $p<0,05)$. Dari analisis tersebut sarana praktik memberikan sumbangan terhadap hasil belajar patiseri sebesar $49 \%\left(\mathrm{R}^{2}=0,490\right)$.

Terdapat pengaruh positif dan signifikan antara media pembelajaran terhadap hasil belajar patiseri pada siswa Program Keahlian Tata Boga SMK Se-Gerbangkertasusila $\left(\mathrm{r}_{\mathrm{x} 4 \mathrm{y}}\right.$ $=0,735 ; p<0,05)$. Dari analisis tersebut media pembelajaran memberikan sumbangan terhadap hasil belajar patiseri sebesar 54\% $\left(\mathrm{R}^{2}\right.$ $=0,540$ ).

Terdapat pengaruh positif dan signifikan secara bersama-sama antara strategi pembelajaran, gaya belajar, sarana praktik, dan media pembelajaran terhadap hasil belajar patiseri pada siswa Program Keahlian Tata Boga SMK Se-Gerbangkertasusila $\left(\mathrm{r}_{\mathrm{x} 1, \mathrm{x} 2, \mathrm{x} 3, \mathrm{x} 4 \mathrm{y}, \mathrm{y}}\right.$ $=0,749 ; p<0,05)$. Dari analisis tersebut strategi pembelajaran, gaya belajar siswa, sarana praktik, dan media pembelajaran secara bersama-sama memberikan sumbangan terhadap hasil belajar patiseri sebesar $56 \%\left(\mathrm{R}^{2}\right.$ $=0,560)$.

\section{Saran}

Berdasarkan hasil penelitian dan pembahasan serta kesimpulan, maka beberapa saran dapat dikemukakan sebagai berikut.

Strategi pembelajaran yang diterapkan guru di sekolah masih berkategori sedang. Artinya diperlukan usaha untuk memperbaiki strategi pembelajaran di sekolah untuk menunjang pembelajaran patiseri. Strategi yang didominasi ceramah diubah menjadi berpusat pada siswa, sehingga siswa terlibat aktif dalam pembelajaran.

Siswa hendaknya mengembangkan gaya belajar masing-masing sesuai dengan potensi yang ada di dalam dirinya. Sehingga diharapkan pemahaman tentang patiseri dapat meningkat dengan gaya belajar yang sesuai.

Penyediaan sarana praktik dalam pembelajaran patiseri mutlak diperlukan. Sekolah harus meningkatkan penyediaan sarana praktik di sekolah untuk mempersiapkan siswa memasuki dunia kerja yang sesungguhnya.

Media pembelajaran yang digunakan oleh guru harus bervariasi untuk menarik minat siswa dalam pembelajaran di kelas. Dengan 
peningkatan minat siswa, hasil belajar patiseri juga akan meningkat.

Penelitian ini hanya mengetahui besar pengaruh strategi pembelajaran, gaya belajar siswa, sarana praktik, dan media pembelajaran. Untuk peneliti lain yang akan datang disarankan untuk meneliti kondisi riil di lapangan sehingga diperoleh kerangka model yang lengkap.

\section{DAFTAR PUSTAKA}

Achir, B. (2009). Merencanakan kebutuhan program praktik dan optimalisasi pemakainyaan. PPGT, Bandung.

Azhar, Arsyad. (2007). Media pembelajaran. Jakarta: PT. Radja Grapindo Persada.

Benjamin, S. Bloom. (1956). The Taxonomy of Education Objectives, the Classification of Educational Goals, Handbook I : Cognitive Domain. New York: David McKay Company, Inc.

Bruner, J.(1986). The Culture of Education. New York : Havard University Press.

Depdiknas. (2008).Peraturan Menteri Pendidikan Nasional Nomor 40 Tahiun 2008 Tanggal 31 Juli 2008 tentang Standar Sarana dan Prasarana Sekolah Menengah Kejuruan/Madrasah Aliyah Kejuruan (SMK/MAK).

Farida, Anni, dkk. (2008). Patiseri Jilid 1 SMK. BSE. Jakarta: Direktorat Pembinaan Sekolah Menengah Kejuruan, Direktorat Jenderal Manajemen Pendidikan Dasar dan Menengah, Departemen Pendidikan Nasional.

Furqan. (2009). Karakteristik belajar siswa ( http : //www.alfurqan.or.id)
Heinich, Molenda, Russell, Smaldino.(2005). Instructional technology and media for learning $8^{\text {th }}$ edition. NewJersey: Pearson Merrill Prentice Hall.

Koper, Rob. (2005). Learning design. Netherland: Educational Technology Expertise Centre Open University of the Netherlands.

RudyBudiman. 2008. Media pembelajaran. Materi Diklat Terakreditasi Guru SD Semester2. Bandung: PPPPTKTK danPLB.

Sharp,V. (2005). Computere ducation for teachers: Integrating technology into classroom teaching. New York: McGrawHill.

Sugiyono. (2012). Metode penelitian pendidikan pendekatan kuantitatif, kualitatatif, dan R\&D. Bandung: Penerbit Alfabeta.

Sugiyono. (2010). Statistik untuk Penelitian. Bandung: Penerbit Alfabeta.

Suryabrata, Sumadi. (2011). Metodologi penelitian. Jakarta: Rajawali Pers.

Wilson, Scott. (2005). Architectures to Support Authoring and Content Management with Learning Design. Netherland: Educational Technology Expertise Centre Open University of the Netherlands.

Vogten, Hubert. (2005). An architecture for learning design engines. Netherland: Educational Technology Expertise Centre Open University of the Netherlands. 